\title{
Obituary
}

\section{MARGARET ESTHER ROWBOTTOM}

1908-1999

Dr Margaret Rowbottom, who died after a short illness on 25 November 1999, aged 91, was on the staff of the Wellcome Historical Medical Museum from 1933 to 1968 and a pivotal figure throughout the 1950s and early 1960s. She was also a notable historian of science.

Margaret Rowbottom graduated BSc in physics at Bedford College, London University, in 1930. A year at Macclesfield High School decided her against a career in teaching but, with an invalid mother to support, a job was essential and an enquiry about opportunities with Burroughs Wellcome led to her engagement as a junior assistant in the ethnographical section of the Museum in December 1933. She took an additional BSc in anthropology, in her own time, in 1936 and was promoted to the senior scientific staff in 1939. From 1939 to 1945 she served in the WAAF, was commissioned in 1941, and was mentioned in dispatches for secret telecommunications intelligence work. She completed an MSc in the history of science in her spare time in 1943, surely the only WAAF officer whose luggage contained a set of Boyle's works, borrowed from the London Library.

Margaret's return to the Museum at the end of 1945 coincided with the appointment of Dr Edgar Ashworth Underwood as Director. The Museum, closed since 1932, was scheduled to reopen in October 1946 with an exhibition on the history of anaesthesia. Margaret had been designated as the Museum's eighteenth-century specialist, but, following the sudden death of Alec Haggis, she took on the challenge of the anaesthesia exhibition, at short notice, and thereafter acted as Underwood's principal assistant.

With staff and space much reduced after the Museum's temporary exile to Portman Square in 1947, Margaret became responsible, like Pooh-Bah, for "everything else" that was not archaeology (Donald Lacaille, later David Dixon), ethnography (Rosa Burstein, later Klaus Wachsmann) or "Art Department" (C A Earnshaw), though that eventually devolved on her in 1957. She supervised all aspects of the running of the Museum and its stores, conducted visiting parties, and ran the photographic service. Between 1947 and 1962 she organised 18 major exhibitions, involving much recataloguing of objects, and in 1959 arranged the series of historic pharmacies in the entrance hall of the Wellcome Building.

Despite this heavy work load, which regularly extended beyond working hours, she maintained her academic interests. She was an early member of the British Society for the History of Science, served on council in 1956-60 and 1962-66, and as a vice-president in 1959-62. Robert Boyle was a long-standing interest: in 1950 she described in Annals of Science her discovery of his first published essay; her $\mathrm{PhD}$ thesis in 1955 was on The chemical studies of Robert Boyle, and a paper on his Huguenot connections appeared in Proceedings of the Huguenot Society in 1961.

Dr Underwood retired in 1964 and, with her own retirement approaching, Margaret was not required to participate in Noël Poynter's radical reshaping of the Museum. Instead she concentrated on the history of medical electricity, which had interested her since an exhibition in 1956, and from 1967 worked at home, caring for an invalid friend. This restricted her own mobility, but her magnum opus, Electricity and medicine, history of their interaction, written with Charles Susskind, eventually appeared in 1984.

She enjoyed an active retirement, with a wide circle of friends and godchildren, was an active member of her church, and worked for numerous charities. She regularly attended 


\section{Obituary}

Wellcome functions, including in 1987 the opening of the exhibition No laughing matter, historical aspects of anaesthesia, 41 years after her own exhibition.

I am grateful to Margaret's god-daughter, Gwyneth Love, for making available an autobiographical typescript.

John Symons 